Agro-Science Journal of Tropical Agriculture, Food, Environment and Extension Volume 17 Number 2 (May 2018) pp. 18 - 26

ISSN 1119-7455

\title{
OCCURRENCE AND POPULATION DISTRIBUTION OF PLANT PARASITIC NEMATODES ASSOCIATED WITH ROSELLE (Hibiscus sabdariffa L.) IN NORTHERN NIGERIA
}

\author{
Ogunsola, K. E. ${ }^{1-2}$, Ogunfunmilayo, A. O. ${ }^{1}$, Solomon, S. ${ }^{1}$, Oluitan, J. A. ${ }^{1}$, Kazeem, S. A. ${ }^{1}$, \\ Folorunso, D. O. ${ }^{1}$ and Ibrahim, S. ${ }^{1}$

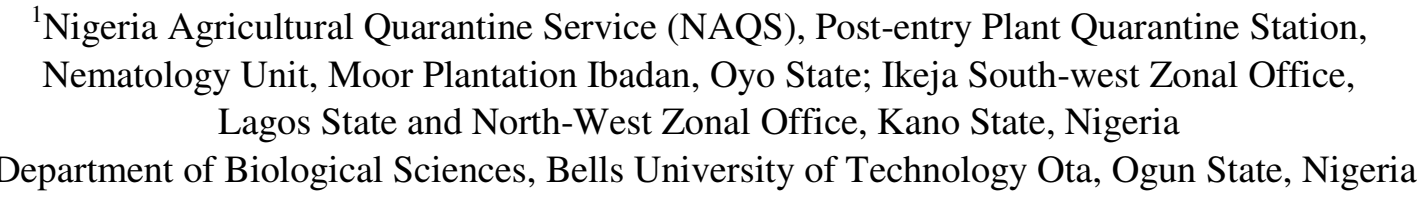

Correspondence author mail: kayodeogunsola@yahoo.co.uk

\begin{abstract}
Pests including nematodes have been reported as a limiting factor to the production of roselle worldwide.A survey of rosellefarmsinsix Northern Sates of Nigeria was conductedin 2013 to identify the diverse nematode species associated with the soils and roots of the plant and determine their population densities on farmers' fields. Eightsoil and ten plant samples were randomly collected from each of twenty farms from which nematodes were extracted and identified. Four genera of plantparasitic nematodes (Meloidogyne spp.,Helicotylenchus spp., Rotylenchulus spp.and Tylenchus spp.) were found in association with roots and rhizosphere of roselle plants. Meloidogyne were most populous (62.29\%) on the roots while Tylenchuswas least (1.68\%). Helicotylenchus spp appeared in highest density (50.05\%) in plant rhizosphere, but not identified from the roots. The highest percentage of nematode population (22.7\%) wasfrom Katsina, followed by Sokoto (21.6\%), Jigawa (17.4\%), Zamfara (16.5\%), Kano (15.1\%) and Kaduna states (6.7\%).The generally low nematode density observed might be due to low precipitation and high soil temperature of the six states.Occurrence of varied species of nematodes demands effective control measures for improved roselle productivity. Kano, Zamfara and Jigawawith low nematode population densities can be considered for further research towards the establishment of pest-free areas or area of low pest prevalence for roselle nematodes in Nigeria, useful in the agricultural export trade. Further studies are required on the determination of density economic threshold and the definitive roles of nematodes in causing low productivity of roselle.
\end{abstract}

Keywords: Export value, Hibiscus sabdariffa, nematodes, population densities, pest-free area

\section{INTRODUCTION}

Roselle (Hibiscus sabdariffaL.) also called rosella, sorrel or java jute is a fibre crop of the family Malvaceae. It is probably native to West Africa although known in the West Indies early in the $16^{\text {th }}$ century and was growing in Asia by the 17th century (EBI, 2017). Its extensive cultivation in Indonesia began in the 1920s under a governmentsubsidized program established to obtain fibre for sugar-sack manufacture. It is commercially propagated in different parts of the world including USA, United Kingdom and India while Benin, Sudan, Cote D'Ivoire, Ghana, Niger, Burkina Faso and Nigeria were reported as major areas of roselle cultivation in Africa
(Oyewole and Mera, 2010; Babatunde and Mofoke, 2006)India, Java, and the Philippines are the world major producers (EBI, 2017; Orwa et al., 2009).

The plantis an erect, bushy herbaceous subshrub propagated from seed, widely grown in the tropics and growing to $3 \mathrm{~m}$ height (Fern, 2012). Roselle is usually grown as an annual plant. It is referred to as "zobo" in western Nigeria (the Yorubas call the white variety "Isapa") and "Zoborodo" in Northern Nigeria. The two main varieties of sHibiscus sabdariffa are $H$. sabdariffavar. altissima and $H$. sabdariffa var. sabdariffa race ruber. The variety $H$. sabdariffa has red or pale yellow inflated edible calyces but a poor quality fibre 
while variety altissima has red or green, spiny calyces which are inedible and grown for its jute-like fibre (Fern, 2012).At the base of each flower is a fleshy calyx (sepal of the flowers) which is the part that is harvested and used (Harrinson, 2010). In many tropical areas, the red, somewhat acid calyxes of the variety altissima are used locally for beverages, sauces, jellies, and preserves while the leaves and stalks are consumed as salads or cooked vegetables and used to season curries (EBI, 2017). In Nigeria, roselle cultivation has gained wide acceptability among farmers due to its medicinal (Olaniran et al., 2013) and industrial importance (Aoshima et al., 2007). It is used as a digestive agent, purgative and adiuretic (Osuntogun and Aboaba, 2004) and as afolk medicine for cancer, obesity, diabetes and hypertension (Tabuti et al., 2003). It is also used in food production such as local nonalcoholic beverages, industrial wine, jam, marmalade and tea (Aoshima et al., 2007). Production of non-alcoholic beverage (Zoborodo) from dried red roselle calyces is very popular in Nigeria. A strong fibre obtained from the stem is used for various household purposes including making sackcloth, twine and cord (Bolade et al., 2009). Roselle is cultivated in various agro-ecological zones of Nigeria but highly concentrated in the North Eastern, North Western and Middle belt regions (Oboh and Elusiyan, 2004). However, despite the high economic importance of roselle, especially its potential as acrop with high export value, little attention has been paid to the crop in the areas of important pests and diseases as well as research for improvement. Diseases have been reported as a limiting factor to the production of roselle worldwide (Ooi and Saleh 1999). Many fungal and few bacterial diseases of roselle have been reported from various parts of the world including Nigeria and these include damping-off, vascular wilt, leaf spot, stem and foliar blight, leaf, stem, fruit and root rot (Amusa et al., 2005,\& Nwaukwu andAtaga, 2013). Ogunsola et al. (2016) also reported anincidence of leaf blight, leaf spot, stem wilt, flower decay and leaf discolouration in roselle plants cultivated in northern Nigeria. Apart from fungi, apathogenic bacterium, Bacillus solanacearum, has been isolated from roselle (Orwa et al., 2009).

Nematode infestation has also caused economic yield loss in major crops (Orwa et al., 2009). The root-knot nematode (RKN), Meloidogyne spp. has been reported as one of the most damaging agricultural pests attacking a wide range of crops (Wesemael et al., 2011) and can cause dramatic yield losses, mainly in tropical and sub-tropical agriculture (Moens et $a l ., 2009)$. The cumulative effect of the feeding damage caused by nematodes could have a negative impact on the plant vigour, thereby constituting serious impediments to the growth and yield of the roselle which is the ultimate to farmers (Afolami, 2000). Due to the insidious nature of damage caused by plant-parasitic nematodes (PPN), farmers are in most cases not aware of them and often times do not control nematodes on the field, making yield decline unavoidable. Despite the reported occurrence of some RKN such as Meloidogyne arenaria, $M$. incognita and $M$. javanica (Orwa et al., 2009; Adegbite et al., 2014) and Heterodera rudicicola (McClintock and Tahir, 2004), there is limited knowledge of parasitic nematode diseases of roselle, especially from the commercial roselle producing parts of Nigeria. Such information is vital for the establishment of pest free areas (PFA) or area of low pest prevalence (ALPP) in Nigeria, which is used in agricultural export trade provided such area is under phytosanitary measures (FAO, 1995; ISPM, 1999). Thus, due to the high commercial and export values of roselle with inadequate documented information on the status of the quarantine nematode pests in Nigeria, this study was conducted to investigate the occurrence and distribution of PPN of roselle in six Northern states of Nigeria.

\section{MATERIALS AND METHODS}

Survey of nematodes associated with roselle Survey of PPN associated with roselle was carried out in six major roselle producing States in Nigeria (Kano, Kaduna, Zamfara, Sokoto, Katsina and Jigawa) between April and May, 2013. Twenty - two (22) roselle farms were arbitrarily selected in thirteen Local Government Areas (LGAs) of the six states (Figure 1). Within each roselle field, ten (10) roselle plants were randomly selected along a ' $\mathrm{W}$ ' shaped path irrespective of the size of the farm, making a total number of two hundred and twenty (220) roselle plants sampled for nematode extraction. Extension agents from Agricultural Development Projects (ADPs) of each of the States were employed to overcome language barrier, enhance locating farms, and access to the roselle farmers in the states. Theinter-personal interview was also carried out between scientists/extension officers and the farmers to obtain their demographic data and cropping history, including information on nematode infestation 
and control measures. Geo-references of each point surveyed (location /farm name and farm size) were determined using global positioning system equipment (eTrex, Garmin, 12 channels GPS Corporation, Taiwan).

\section{Sampling of soil around roselle plant}

Eight core soil samples were taken per farm to a depth of $15-30 \mathrm{~cm}$ around the plant root using soil auger of diameter $1.9 \mathrm{~cm}$. The soil samples were sealed in polythene bags and kept away from sun. Samples were properly labelled and taken to Nematology Research Laboratory, Nigeria Agricultural Quarantine Service, Moor Plantation Ibadan for analysis and identification of PPN.

\section{Extraction and identification of nematode from soil}

Bulked sample per roselle plant was gently mixed by hand and two hundred grams (200 g) of sub-soil was taken for nematode assayusing the Whitehead and Hemming (1965) tray modification of Baermann technique described as follows: Two hundred grams (200 g) of soil was put into a set up that has two plastic sieves with double-ply tissue sandwiched in between them. The plastic sieves with the soil were thereafter placed in a plastic bowl and water was added to the extraction bowl just enough to wet the soil. The set-up was left undisturbed for 48 hours in the laboratory. Thereafter, the plastic sieve (of mesh size $45 \mu \mathrm{m}$ ) containing the soil was removed briskly, and the nematode suspension in the bowl was poured into a $500 \mathrm{ml}$ Nalgene wash bottle and allowed to settle (Caveness, 1975). The supernatant was siphoned out with a rubber tube, and the suspension containing nematodes was then poured into the Doncaster (1962) nematode counting dish and examined under a stereomicroscope. Nematodes were transferred with a sharpened broomstick to a slide containing a drop of water, covered with a coverslip and examined under a compound microscope (Navite Olympus, China) with X40 and X 100 magnifications for identification.

\section{Sampling of roselle roots for nematode}

Root samples were taken by lifting whole roselle plant from the soil using a spade (Coyne et al.,2007) so that the galls and root lesions could be observed from the roots in situ. Roots were collected at the same location as for soil and were combined in the same sample bag, such that the soil prevented degeneration of the roots before laboratory processing. Both roots and soil samples were placed in ice-box. The samples were then transported to the laboratory and stored at $10^{\circ}$ $\mathrm{C}$ for thorough symptomatology and nematode laboratory assay.

\section{Extraction and identification of nematode from plant roots}

Whole root system collected per plant were freed of soil, washed under a gentle stream of cool tap water, mopped dry and weighed in the laboratory. The roots were separated into live (functional) and dead (non-functional) roots. Thereafter, live roots were cut transversely with scissors into about $1-2 \mathrm{~cm}$ pieces, mixed carefully and $10 \mathrm{~g}$ sub-sample was assayed for nematode using the Whitehead and Hemming (1965) tray modification of Baermann technique. A $10 \mathrm{~g}$ sub-sample root was put in a blender with some quantity of water and macerated for 30 seconds. The macerated suspension was then poured into a Whitehead and Hemming (1965) set up as previously described. Thereafter, the plastic sieve containing the macerated roots was removed briskly, and the nematode suspension in the bowl was poured into a $500 \mathrm{ml}$ nalgene wash bottle and allowed to settle (Caveness, 1975). The supernatant was siphoned out with arubber tube, and the suspension containing nematodes was then poured into the Doncaster (1962) nematode counting dish and examined under a stereo and compound microscope as previously described. Identification of PPN was done with the aid of a compound microscope using the simplified pictorial nematode key of Mai and Lyon (1975). Nematode population was determined by counting and population data were expressed in percentage.

\section{RESULTS}

Roselle farmers in the surveyed area were between 20 and 68 years old with 10 to 54 years of farming experience. Their farm sizes ranged from 0.04 hectare in Daura, Katsina state to 3.45 hectares in Tsuburowa, Jigawa state (Table 1). The seed for planting were sourced from open markets and fellow farmers, with few from ADPs offices. Roselle plants on surveyed farms were 2 to 3 months old and both mixed cropping (with either sorghum, maize or cowpea) and sole cropping were practised by the farmers. Many farmers in the study areas shifted from cultivating roselle to other crops due to poor marketing and while only one roselle farm per LGAs was found in some locations, two or three farms were observed in others. Foliar symptoms of insect pest infestation, disease infection and root galls were observed in some of the plants on the fields while other farms looked apparently healthy. 


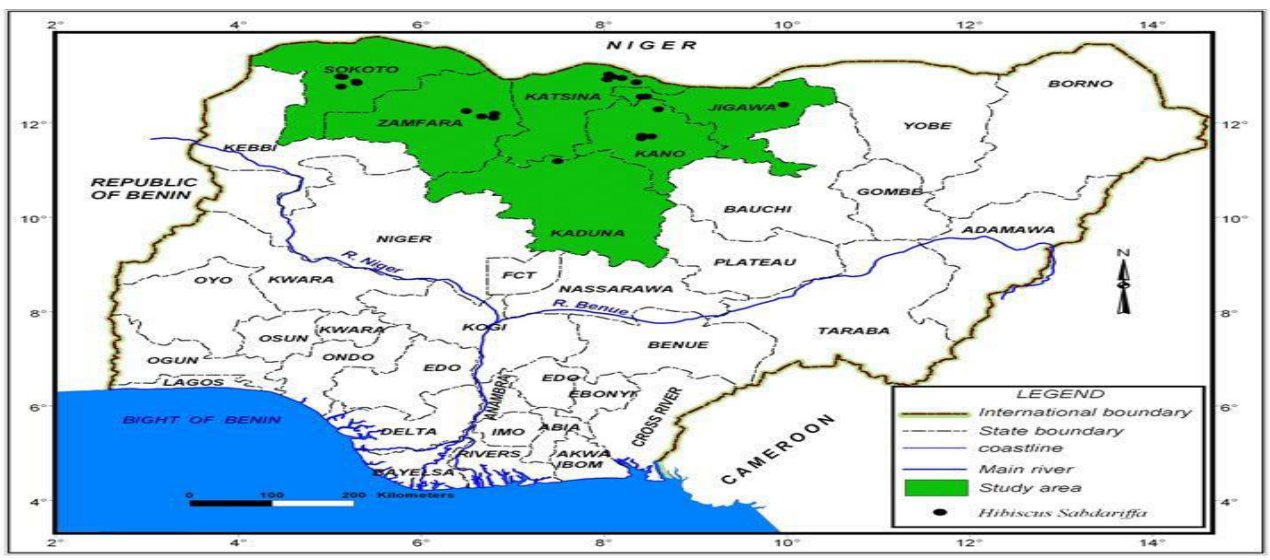

Figure 1: Map of Nigeria showing the six states surveyed for plant parasitic nematodes
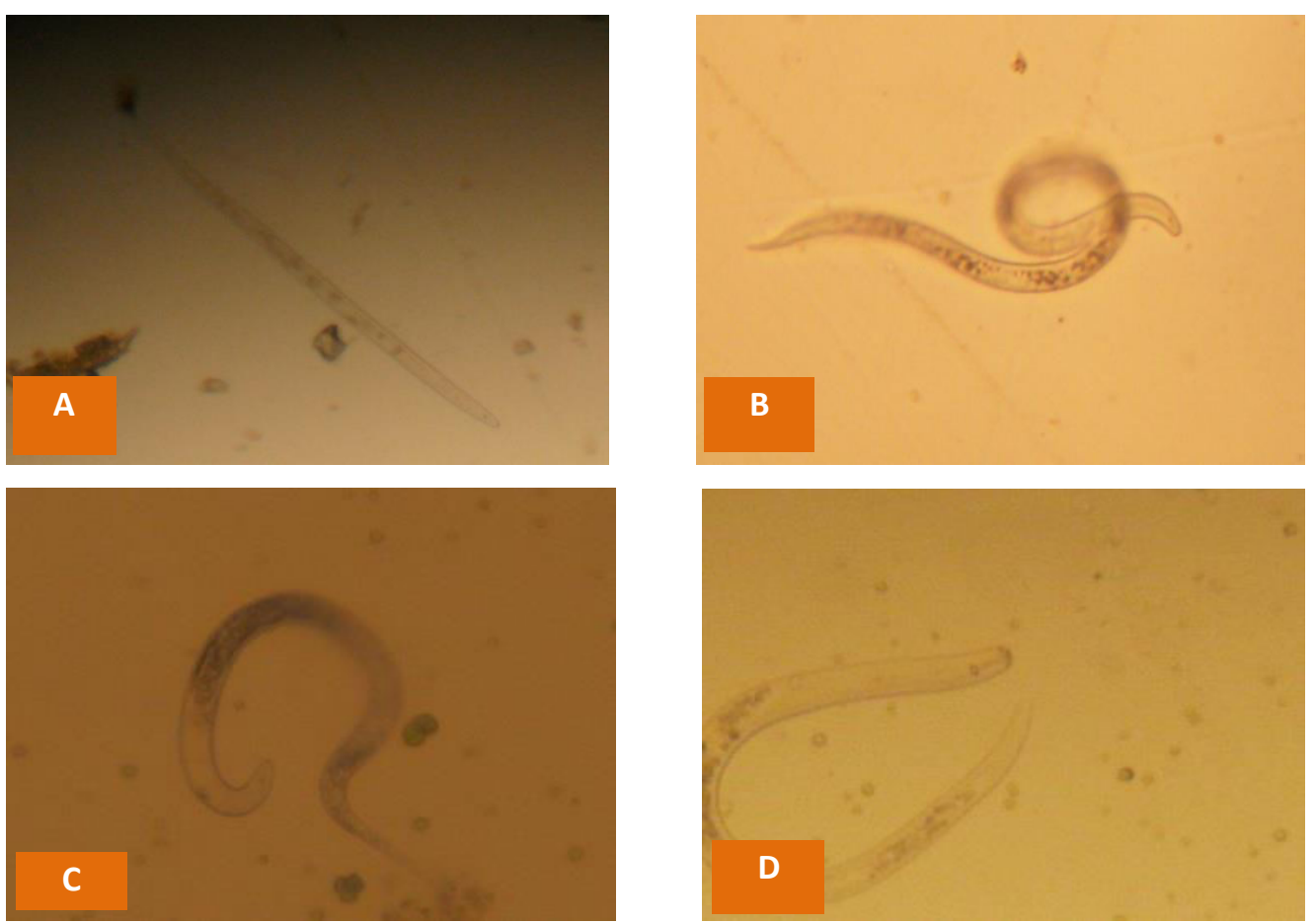

Plate 1 (A - D): Micrographs of plant-parasitic nematodes extracted from roselle plants.(A) Meloidogyne spp(male), (B)Rotylenchulus spp, (C) Tylenchus spp and (D)Helicotylenchus spp (X 60)

Four genera of plant-parasitic nematodes were observed to be associated with roselle plants in Kano, Kaduna, Zamfara, Sokoto, Katsina and Jigawa states of Nigeria. The nematodes, extracted from the soil and roselle roots in twenty-two roselle farms were Meloidogyne spp, Helicotylenchus spp, Rotylenchulus spp and Tylenchus spp (Plate 1). These nematodes were identified from the soil or roselle root samples in all the six states but with avaried population. The population densities of all the four nematode genera (Table 1) showed highest percentage nematode population (22.7 $\%$ ) from Katsina state, followed by Sokoto $(21.6 \%)$, Jigawa $(17.4 \%)$, Zamfara $(16.5 \%)$, Kano $(15.1 \%)$ and Kaduna state $(6.7 \%)$.
Nematodes were observed in both soil and root in most of the farms studied but few farms showed anabsence of nematode in either soil or root while a farm (Shargale) in Katsina state had no Rotylenchus spp. in both soil and roots. Some farms in Sokoto (Maganawy I), Zamfara (Kotor Koshi) and Kano states (Danbatta) showed low nematode densities whereas others within the same state or LGAs [(e.g. Sokoto (Tsebe/Lugan1) and Zamfara states (Bungudu)] or in other states [e.g. Jigawa (Tsuburowa)] produced high nematode population. Higher nematode population was observed in the soil than plant roots. Helicotylenchus spp., Tylenchus spp.,Meloidogyne spp. and Rotylenchulus spp. 
were extracted from the soil at population densities of $50.05 \%, 19.56 \% 16.67 \%$, and $13.70 \%$ respectively (Table 2 ). However, Meloidogyne spp., Rotylenchulus spp. and Tylenchus spp. were abundant in roots of roselle plants at $62.29 \%, 36.03 \%$ and $1.68 \%$ population respectively (Table 3 ). The genus Helicotylenchus spp., though most prominent in the soils of the farms across the six states, was not observed in roselle roots in all the farms (Tables 1 and 3). Meanwhile, Meloidogyne spp. population was highest from the roselle roots. Out of the total nematode population, $92.86 \%$ were extracted from the soil while only $7.14 \%$ nematode population were from plant roots (Tables 2 and 3). Higher soil $(97.05 \%)$ to root $(2.95 \%)$ population ratio of the four nematode genera was observed in Kaduna state while the lowest ratio (87.33 to $12.67 \%$ ) was found in Zamfara state.

\section{DISCUSSION}

A detection survey of roselle farms in six northern states of Nigeria revealed some diversity of types and population levels of PPN in soils and roots of roselle plants. The roselle farmers have long (10 to 54) years of farming experience which might enhance commercial roselle production for local and international markets. Four nematode genera: Meloidogyne spp., Helicotylenchus spp., Rotylenchulus spp.and Tylenchus spp. were detected from the twenty-two farms investigated. The results are similar to earlier reports (Michel et al., 2005) that roselle is frequently grown in environments that are conducive to root knot and reinform nematodes. This study showed that while the highest population of Helicotylenchus spp. was observed in the soils across the six states, Meloidogyne spp were most abundant in the roots of roselle plants. Asimilar result was reported on the two nematode genera in northern Nigeria (Agbenin and Ogunlana, 2006) which also agrees with the findings of Orwaet al. (2009), and Adegbite et al. (2014) that Meloidogyne arenaria, $M$. incognita and $M$. javanica were the main parasitic nematodes of roselle. Nematode population was higher in the soils of roselle farms than in the roots. This has been earlier reported in northern Nigeria (Agben in and Ogunlana, 2006). Surprisingly, Helicotylenchus spp. that was most prominent in the soils of the farms across the six states, was not found in roselle roots from any of the farms. This rare occurrence might be due to the genus Helicotylenchus being usually ectoparasites (van der Putten et al., 2005) though some are semi-end parasites (Yeates et al., 1993) or to some level of resistance to nematodes which has been reported in roselle (Heffes et al., 1991).

It was also observed that none of the farms in the study areas was free of nematodes and the population densities of the four extracted nematode genera varied with location and type. Factors contributing to such widespread distribution of the nematodes might include over cultivation of a single common cultivar and other environmental factors such as soil type as well as the presence of a suitable alternate host (Bafokuzara, 1996). Also, farm practices such as continuous cropping and monoculture with a single cultivar, which is prevalent with Nigerian farmers, might result to build up of nematode pests to levels that may be economically important. It has been reported that species of Meloidogyne are found more frequently in sandy soils than in finer texture soil (Spaull and Cadet, 1991). The slight increase in nematode populations in the four states in the Sudan savanna area than Kaduna and Kano statesmay probably be due to ease of movement of the nematodes through the large soil pore diameter and soil particle size (Idowu, 1981), which are typical properties of a generally sandy soil. This could also account for different population densities of the PPN found in soil and roots of roselle in different locations surveyed. The generally low nematode density observed in the six states might be due to low precipitation and high soil temperature of the survey areas. Beneficial or negative effects of climate on nematode population have been reported earlier (Colagiero and Ciancio (2011).Increase nematode population due to moisture was previously reported (Jordan et al., 1989). Similarly, Gbadeges in et al., (1993) observed a depressed nematode population in dry season in the savanna areas of Nigeria which later increased in the rainy season and got to the peak between August and October. Negative correlation between temperature and nematode abundance has also been reported (Kandel et al., 2013).These climatic and edaphic factors play important roles in determining the abundance and distribution of nematode species. For instance, several Meloidogyne species are known to attack different crops and tend to favour light soil and warm temperatures (Micheal et al., 2005).Thus, the varied population densities among the six northern states might be due to the differences in rainfall distribution and the characteristic soil types of the states surveyed which are located within the Sudan and Guinea savanna zones of Nigeria. 
Ogunsola, K. E., Ogunfunmilayo, A. O., Solomon, S., Oluitan, J. A., Kazeem, S. A., Folorunso, D. O. and Ibrahim. S.

Table 1: Population density of plant parasitic nematodes extracted from $200 \mathrm{~g}$ soil and $10 \mathrm{~g}$ root samples on roselle farms from six states in the northern Nigeria

\begin{tabular}{|c|c|c|c|c|c|c|c|c|c|c|c|c|c|c|}
\hline State & LGA & farm & Farm & Meloid & & Helico & & Rotyle & & Tylenc & & Total & & $\%$ Po \\
\hline \multirow{6}{*}{ Sokoto } & \multirow{3}{*}{ Wamako } & location & size (ha) & soil & root & soil & root & soil & root & Soil & root & farm & state & \\
\hline & & Maganawy I & 0.36 & 33 & 4 & 45 & 0 & 4 & 17 & 10 & 0 & 113 & \multirow[t]{5}{*}{879} & \multirow[t]{4}{*}{21.6} \\
\hline & & Maganawy II & 1.10 & 61 & 3 & 95 & 0 & 13 & 5 & 22 & 2 & 201 & & \\
\hline & Bodinga & Dogon karfe & 1.04 & 84 & 17 & 16 & 0 & 42 & 0 & 20 & 0 & 179 & & \\
\hline & Denge Shuni & Tsehe/Lugan 1 & 0.42 & 52 & 22 & 96 & 0 & 24 & 5 & 30 & 0 & 229 & & \\
\hline & & Tsehe/Lugan 2 & 0.32 & 46 & 16 & 71 & 0 & 17 & 2 & 5 & 0 & 157 & & \\
\hline \multirow[t]{4}{*}{ Zamfara } & Bungudu & Kotor Koshi & 0.31 & 19 & 6 & 46 & 0 & 15 & 2 & 32 & 0 & 120 & \multirow[t]{3}{*}{671} & \multirow[t]{3}{*}{16.5} \\
\hline & & Gada & 0.50 & 22 & 14 & 93 & 0 & 11 & 13 & 41 & 1 & 195 & & \\
\hline & & Bungudu & 0.29 & 8 & 43 & 104 & 0 & 21 & 0 & 20 & 0 & 196 & & \\
\hline & Gusau & Gebawa & 0.36 & 27 & 6 & 65 & 0 & 42 & 0 & 20 & 0 & 160 & & \\
\hline \multirow[t]{4}{*}{ Kano } & Gwulum & Kura & 0.09 & 14 & 2 & 72 & 0 & 18 & 3 & 81 & 0 & 190 & \multirow[t]{4}{*}{614} & \multirow[t]{4}{*}{15.1} \\
\hline & Danbata & Danbatta & 0.14 & 1 & 7 & 63 & 0 & 3 & 9 & 40 & 0 & 123 & & \\
\hline & & Ajumawa & 0.62 & 5 & 6 & 93 & 0 & 5 & 11 & 12 & 0 & 132 & & \\
\hline & & Barebari & 0.66 & 3 & 4 & 124 & 0 & 5 & 2 & 31 & 0 & 169 & & \\
\hline \multirow[t]{5}{*}{ Katsina } & Sandamu & Sabongari & 0.14 & 62 & 1 & 53 & 0 & 21 & 5 & 36 & 0 & 178 & \multirow[t]{3}{*}{920} & \multirow[t]{3}{*}{22.7} \\
\hline & \multirow[t]{2}{*}{ Daura } & Daura & 0.04 & 2 & 1 & 142 & 0 & 11 & 3 & 5 & 0 & 164 & & \\
\hline & & Shargale & 0.25 & 4 & 3 & 92 & 0 & 0 & 0 & 43 & 0 & 142 & & \\
\hline & Mashi & Doka I & 0.34 & 4 & 5 & 130 & 0 & 84 & 4 & 70 & 0 & 297 & & \\
\hline & & Doka II & 0.06 & 2 & 1 & 84 & 0 & 13 & 7 & 32 & 0 & 139 & & \\
\hline \multirow[t]{3}{*}{ Jigawa } & Hadejia & Tsuburowa & 3.45 & 94 & 4 & 152 & 0 & 40 & 8 & 63 & 1 & 362 & \multirow[t]{3}{*}{707} & \multirow[t]{3}{*}{17.4} \\
\hline & Kazaure & Firji & 0.20 & 0 & 2 & 74 & 0 & 95 & 3 & 12 & 1 & 187 & & \\
\hline & & Kurare & 0.07 & 3 & 5 & 52 & 0 & 31 & 6 & 61 & 0 & 158 & & \\
\hline Kaduna & Markarfi & Markarfi & 0.74 & 83 & 6 & 126 & 0 & 2 & 2 & 52 & 0 & & 271 & 6.7 \\
\hline Total & & & & 629 & 178 & 1888 & 0 & 517 & 107 & 738 & 5 & & 4062 & \\
\hline
\end{tabular}

$\%$ Po - Population percentage, Meloid - Meloidogyne species, Helico - Helicotylenchus species, Rotyle $=$ Rotylenchus species,

Tylenc - Tylenchus species, LGA - Local government area 
Table 2: Population density of plant parasitic nematodes extracted from soil (200 g) samples on roselle farms from six northern

\begin{tabular}{|c|c|c|c|c|c|c|c|c|c|c|c|c|c|c|}
\hline Nematode & & Sokoto & Zamfara & & & Kano & & & Katsina & & & Jigawa & Kaduna & Total \\
\hline & Po & $\% \mathrm{Po}$ & Po & $\% \mathrm{Po}$ & Po & $\%$ Po & Po & $\% \mathrm{Po}$ & Po & $\% \mathrm{Po}$ & Po & $\%$ Po & Po & $\% \mathrm{Po}$ \\
\hline \multicolumn{15}{|l|}{ Meloidogyne } \\
\hline $\mathrm{sp}$ & 276 & 35.11 & 76 & 12.96 & 23 & 4.04 & 74 & 8.32 & 97 & 14.33 & 83 & 31.56 & 629 & 16.67 \\
\hline \multicolumn{15}{|c|}{ Helicotylenchus } \\
\hline $\mathrm{sp}$ & 323 & 41.09 & 308 & 52.56 & 352 & 61.75 & 501 & 56.29 & 278 & 41.06 & 126 & 47.91 & 1888 & 50.05 \\
\hline \multicolumn{15}{|l|}{ Rotylenchulus } \\
\hline $\mathrm{sp}$ & 100 & 12.72 & 89 & 15.19 & 31 & 5.44 & 129 & 14.49 & 166 & 24.52 & 2 & 0.76 & 517 & 13.7 \\
\hline Tylenchus sp & 87 & 11.07 & 113 & 19.28 & 164 & 28.77 & 186 & 20.9 & 136 & 20.09 & 52 & 19.77 & 738 & 19.56 \\
\hline Total & 786 & 89.42 & 586 & 87.33 & 570 & 92.83 & 890 & 96.74 & 677 & 95.76 & 263 & 97.05 & 3772 & 92.86 \\
\hline
\end{tabular}

Po - nematode population, $\%$ Po - population percentage

Table 3: Population density of plant parasitic nematodes extracted from roselle root $(10 \mathrm{~g})$ samples from six northern Nigerian States

\begin{tabular}{|c|c|c|c|c|c|c|c|c|c|c|c|c|c|c|}
\hline \multirow[t]{2}{*}{ Nematode } & \multicolumn{2}{|c|}{ Sokoto } & \multicolumn{2}{|c|}{ Zamfara } & \multicolumn{2}{|c|}{ Kano } & \multicolumn{2}{|c|}{ Katsina } & \multicolumn{2}{|c|}{ Jigawa } & \multicolumn{2}{|c|}{ Kaduna } & \multicolumn{2}{|c|}{ Total } \\
\hline & Po & $\%$ Po & Po & $\% \mathrm{Po}$ & Po & $\%$ Po & Po & $\% \mathrm{Po}$ & Po & $\%$ Po & Po & $\%$ Po & Po & $\%$ Po \\
\hline Meloidogyne sp & 62 & 66.67 & 69 & 81.18 & 19 & 43.18 & 11 & 6.18 & 11 & 36.67 & 6 & 75.00 & 178 & 61.37 \\
\hline Helicotylenchus sp & 0 & 0 & 0 & 0 & 0 & 0 & 0 & 0 & 0 & 0 & 0 & 0 & 0 & 0 \\
\hline Rotylenchulus sp & 29 & 31.18 & 15 & 17.65 & 25 & 56.82 & 19 & 63.33 & 17 & 56.67 & 2 & 25.00 & 107 & 36.89 \\
\hline Tylenchus sp & 2 & 2.15 & 1 & 1.18 & 0 & 0 & 0 & 0 & 2 & 6.67 & 0 & 0 & 5 & 1.72 \\
\hline Total & 93 & 10.58 & 85 & 12.67 & 44 & 7.17 & 30 & 3.26 & 30 & 4.24 & 8 & 2.95 & 290 & 7.14 \\
\hline
\end{tabular}

Po $=$ nematode population, $\%$ Po $=$ population percentage

Arcent survey on collection and evaluation of roselle germplasm in Nigeria has shown Kaduna and Jigawa as parts of the four states with the highest roselle accessions, suggesting areas of greatest diversity of genetic resources in Nigeria (Dauduet al., 2015). Such high crop intensity have been reported to result into increased nematode density (Kandel et al.,2013) which might be responsible for the higher nematode population observed in Jigawa than Kano state. Highest nematode population was observed in Katsina state with lowest from Kaduna. However, since only one farm was accessed in Kaduna state due to limited roselle farms, Kano, Zamfara and Jigawa states, with low nematode pests in many locations, can be considered for further research towards establishment of pest free areas (PFA) or area of low pest prevalence (ALPP). The establishment of such PFA is important in agricultural export trade (FAO, 1995; ISPM, 1999).

\section{CONCLUSION}

Findings from this study indicate the presence of four genera of plant-parasitic nematodes (Helicotylenchus spp, Tylenchus spp. Meloidogyne spp,and Rotylenchulus spp) associated with roselle in the northern Nigeria. This suggests the need for roselle farmers in Nigeria to source for planting materials (seeds) from ADPs or farmers shops and not from established farmlands in their locality or local markets which can expose their farmlands to the danger of infection by nematode pests resident in those fields. This could result in the further spread and distribution of the pathogen in the country and its consequence reduction in roselle's productivity. Kano, Zamfara and Jigawa states with low nematode densities are recommended for further research towards the establishment of pest-free areas or area of low pest prevalence for nematodes in Nigeria, which is useful in the agricultural export trade. Further studies are required on the determination of density economic threshold, the definitive roles of nematodes in low productivity of roselle and development of disease-resistant seed varieties.

\section{REFERENCES}

Adegbite A., Agbaje G. and Abidoye J. (2014). Assessment of yield loss of roselle (Hibiscus Sabdariffa L.) due to root-knot nematode, Meloidogyne Incognita under field conditions. Journal of Plant Protection Research,48 (3), 267-273

Afolami S.O. (2000). Suggestions for the improvement of current methods of studying and reporting resistance to root-knot nematodes. International Journal of Nematology, 10 (1), 94100

Agbenin O.N. and Ogunlana M.O. (2006). Occurrence of fusarium wilt and nematodes on red calyx roselle (Hibiscus sabdariffa L.) in northern Nigeria. Journal of Plant Protection. Research,46 (2), 117-122

Amusa N.A., Adegbite, A.A and Oladapo M.O. (2005). Vascular wilt of roselle (Hibiscus sabdariffa L. var. sabdariffa) in the humid forest Region of South-western Nigeria. Journal of Plant Pathology,4 (2), 122-125

Aoshima H., Hirata S. and Ayabe S. (2007). Antioxidative and anti-hydrogen peroxide 
activities of various herbal teas. Food Chemistry, 103, 617-622

Babatunde F.E. and Mofoke A.L.E. (2006). Performance of roselle (Hibiscus sabdariffa L) as influenced by irrigation schedules. Pakistan Journal of Nutrition, 5, 363-367

Bafokuzara N.D. 1996. Incidence of different nematodes on vegetable and fruit crops and preliminary assessment of yield loss due to Meloidogyne species in Uganda. Nematol Brasileira, 20 (1), 32-43.

Bolade M.K., Oluwalana. I.B. and Ojo O. (2009). Commercial practice of roselle (Hibiscus sabdariffa L.) beverage production: optimization of hot water extraction and sweetness level. World Journal of Agricultural Sciences , 5 (1), 126-131

Caveness F.E. (1975). A simple siphon method for separating nematodes fromexcess water. Nematropica, 5, 30-32

Colagiero M. and Ciancio. A. (2011). Climate changes and nematodes: Expected effects and perspectives for plant protection. Journal of Zoology 94, 113-118

Coyne D.L., Nicol J.M. and Claudius-Cole B. (2007). Practical plant nematology: A field and laboratory guide pp 27-28

Daudu O.A.Y., Falusi O.A., Dangana M.C., Abubakar A., Yahaya S.A and Abejide, D.R (2015). Collection and evaluation of roselle (Hibiscus sabdariffa L.) germplasm in Nigeria African Journal of Food Science. 9 (3), 92-96. Doi: 105897/AJFS2014.1225

Doncaster C.C. (1962). A counting dish for nematodes. Nematologica 7, 33-336

EBI (Encyclopaedia Britannica Inc. (2017). Roselle plant. https://www.britannica.com/plant/ roselle-plant. Retrieved 20/01/2017

FAO. (Food and Agriculture Organization of the United Nations) (1995). Requirements for the establishment of pest free areas. ISPM 4. 1995. Rome, IPPC, FAO. Publication history: Last modified August 2011.

Fern K (2012). Plant for a future (PFAF).Hibiscus sabdariffa L. http://www.pfaf.org/ user/Plant.aspx?Lat in Name= Hibiscus+sabdariffa. Retrieved 8th May, 2016.

Gbadegesin R.A., Adesiyan S.O., Khan F.A. (1993). Effects of seasonal changes on the population levels of some plant-parasitic nematodes in the plantations of Pinus caribaea and $P$. oocarpa in the savanna areas of Nigeria. Forest Ecology and Management, 60 (3), 346-353. Doi.org/10.1016/03781127(93)90088-5.

Harrinson M. (2010). Hibiscus sabdariffa (Roselle). Can2grow.http://davesgarden. com/ guide s/articles/view/2909/. Retrieved 8th May, 2016.

Heffes T.P. Coates-Beckford P.L. and Robotham, H. (1991). Effects of Meloidogyne incognita on growth and nutrient content of Amaranthus viridis and two cultivars of Hibiscus sabdariffa. Nematropica, 21 (1), 7-18

Idowu A.A. (1981). The distribution of root-knot nematodes, Meloidogyne spp. in relation to elevation and soil type in vegetable growing areas of upper Northern Nigeria. In: Proceedings of the 3rd Research Planning Conference on root-knot nematodes, Meloidogyne spp., November 1620. IITA Ibadan. Nigeria

ISPM (International Standards for Phytosanitary Measures) 10. (1999). Requirements for the establishment of pest free places of production and pest free production sites. Rome, IPPC, FAO

Jordan E.M., De Waele D. and van Rooyen P.J. (1989). Endoparasitic nematodes in maize roots in the Western Transvaal as related to soil texture and rainfall. Journal of Nematology 21, 356-360.

Kandel S..L., Smiley R.W., Garland-Campbell K., Elling A.A., Abatzoglou J., Huggins, D. Rupp R. and Paulitz T. C. (2013). Relationship between climatic factors and distribution of Pratylenchus spp. in the dryland wheatproduction areas of eastern Washington. Plant Disease, 97, 1448-1456. doi:10.1094/PDIS11-12-1060-RE

Mai W.F. and Lyon H.H. (1975). Pictoral key to genera of plant-parasitic nematodes, 4th Edition. Cornerstone Publishing Associates. A Division of Cornell University Press, pp.219.

McClintock N.C. and Tahir I.M.E. (2004). Hibiscus sabdariffa L. In: Grubben G.J.H. Denton O.A. (editors). Vegetables/Legumes. Wageningen, Netherlands: PROTA; 2004.

Michel LUC., Richard A., Sikora and John Bridge (2005). Plant parasitic nematodes in subtropical and Tropical Agriculture. 2nd Edition. 493520. Moens, M., Perry. R.N., Starr, J.L. (2009) Meloidogyne species - A diverse group of novel and important plant parasites. In: Perry RN, Moens M, Starr J.L., editors. Rootknot Nematodes. Wallingford, UK: CAB International. 1-17

Nwaukwu, I.A. and Ataga, A.E. (2013). Effect of some pathogenic microorganisms on germination and seedling growth of Hibiscus sabdariffa. Nigeria Journal of Mycology .5, 1826

Oboh, G. and Elusiyan, C.A. (2004). Nutrient composition and antimicrobial activity of sorrel drinks (soborodo). J. Med. Food,7 (3), 340342

Ogunsola K.E., Ogunfunmilayo A.O., Oluitan, J.A., Kazeem, S.A., Folorunso, D.O. and Ibrahim, S. (2016). Incidence and distribution of Roselle (Hibiscus sabdariffa L.) diseases of Quarantine importance in six Northern states of Nigeria. Nigerian Journal of Plant Protection.30 (1), 46-59

Olaniran O..A., Alao F.O. and Adebayo T.A. (2013). Control of foliage pests of roselle (Hibiscus Sabdariffa L.) using plant extracts of Tephrosia Vogelii and Azardiractha Indica in Ogbomoso, Nigeria Transnational Journal of Science and Technology. 3 (6), 51-62. ISSN 1857-8047

Ooi K.H. and Saleh, B. (1999). Vegetative compatibility groups of Fusarium oxysporum, the causal organism of vascular wilt on roselle in Malaysia. Biotropia 12: 31-41 
Orwa C., Mutua A., Kindt R., Jamnadass R and Simon. A. (2009). Agroforest tree Database: a tree reference and selection guide version 4.0. Sited 10th February, 2016.

Osuntogun, B. and Aboaba, O. (2004). Microbiological and Physico-chemical Evaluation of some non-alcoholic Beverages. Pakistan Journal of Nutrition, 3, 188-192

Oyewole, C.I. and Mera, M. (2010). Response of roselle (Hibiscus sabdariffa L.) to rates of inorganic and farmyard fertilizers in the Sudan savanna ecological zone of Nigeria. African Journal of Agricultural Research. 5, 23052309

Spaull V.W. and Cadet P. (1991). Nematode Parasites of Sugar cane. In: Plant-Parastic Nematodes in subtropical and tropical Agriculture. M.LVC, R.A Sikora and J. Bridge tds), P.461-491. Wallingford, U.K CAB International

Tabuti J.R.S., Lye K.A. and Dhillion S.S. (2003). Traditional herbal drugs of Bulamogi, Uganda: Plants, use and administration. $J$. Ethnopharmacol., 88, 19-44.

Transnational Journal of Science and Technology. 3 (6), 51-62. ISSN 1857-8047 van der
Van der Putten W.H., Yeates G.W., Duyts H., Schreck Reis C. Karssen G.(2005). Invasive plants and their escape from root herbivory: a worldwide comparison of the root-feeding nematode communities of the dune grass Ammophila arenaria in natural and introduced ranges. Biol. Invasions 7, 733-746

Wesemael W.M.L., Viaene N., Moens M., (2011) Root-knot nematodes (Meloidogyne spp.) in Europe. Nematology 13, 3-16

Whitehead A.F. and Hemning J.R. (1965). A comparison of some quantitative methodes of extracting semi veriform nematodes from soil. Annals of Applied Biology. 55, 25-28

Yeates G.W. Bongers T. de Goede R.G.M. Freckman D.W. Georgieva S.S. 1993. Feeding habits in soil nematode families and generaan outline for soil ecologists. J. Nematol, .25 (3), 315-331. 